\title{
Cellulolytic and mannanolytic aerobic bacteria isolated from Buffalo rumen (Bubalus babalis) and its potency to degrade fiber in palm kernel meal
}

\author{
SITI LUSI ARUM SARI ${ }^{1,2,}$, , TRIYANTO TRIYANTO ${ }^{3}$, ZUPRIZAL ZUPRIZAL ${ }^{4}$, \\ IRFAN DWIDYA PRIJAMBADA ${ }^{5, \text { } ४}$ \\ ${ }^{1}$ Program of Biotechnology, Graduate Shool, Universitas Gadjah Mada. Jl. Teknika Utara, Pogung, Sleman 55284, Yogyakarta, Indonesia \\ ${ }^{2}$ Department of Biology, Faculty of Mathematics and Natural Sciences, Universitas Sebelas Maret. Jl. Ir. Sutami 36A, Surakarta 57126, Central Java, \\ Indonesia. Tel./fax.: +62-271-663375, ^email: siti.lusi.a@ugm.ac.id \\ ${ }^{3}$ Department of Fisheries, Faculty of Agriculture, Universitas Gadjah Mada. Jl. Flora, Bulaksumur, Sleman 55284, Yogyakarta, Indonesia \\ ${ }^{4}$ Department of Feed Nutrition, Faculty of Animal Science, Universitas Gadjah Mada. Jl. Flora, Bulaksumur, Sleman 55284, Yogyakarta, Indonesia \\ ${ }^{5}$ Department of Agricultural Microbiology, Faculty of Agriculture, Universitas Gadjah Mada. J1. Flora, Bulaksumur, Sleman 55284, Yogyakarta, \\ Indonesia. Tel.: +62-274-563062, 901290, Fax.: +62-274-563062, 519717, ^^email: irfan_prijambada@mail.ugm.ac.id
}

Manuscript received: 12 April 2021. Revision accepted: 22 June 2021

\begin{abstract}
Sari SLA, Triyanto T, Zuprifal Z, Prijambada ID. 2021. Cellulolytic and mannanolytic aerobic bacteria isolated from Buffalo rumen (Bubalus babalis) and its potency to degrade fiber in palm kernel meal. Biodiversitas 22: 2829-2837. Palm kernel meal (PKM) is potential to be used as feed, but its high fiber content causes PKM meal difficult to be digested by monogastric animals. Ruminants are especially effective in digesting plant fibers because of the presence of microbes in their rumens. Based on those facts, this research was conducted to obtain mannanolytic and cellulolytic bacteria from buffalo rumens (Bubalus babalis, Linnaeus, 1758), which can degrade fibers in PKM. Bacteria were isolated from buffalo rumen by using PKM- isolation media. Screening of hydrolytic activities was done based on clear zone formation on screening media. A total of five bacterial isolates with the highest hydrolytic activities were then assayed quantitatively for their abilities to degrade mannan and cellulose, then identified based on 16S rRNA gene sequences. This research successfully isolated 34 bacterial isolates. The screening result demonstrated that all isolates could hydrolyze mannan, cellulose and polysaccharide in PKM. Isolate BR25 showed the highest hydrolytic ability on PKM and mannan screening media with clear zone diameter/colony diameter ratio (dz/dc ratio) of 2.99 and 3.53, respectively. Isolate BR31 showed the highest cellulolytic ability with $\mathrm{dz} / \mathrm{dc}$ ratio value of 2.22. Five isolates with the highest hydrolytic activity, i.e. BR14, BR16, BR23, BR25, and BR30 showed the ability to grow on submerged media which contain locust bean gum (LBG) and microcrystalline cellulose (MCC) respectively, as single carbon source and isolate BR25 showed the highest ability to degrade mannan and cellulose. Based on the gene sequence of 16S rRNA, isolates BR14, BR16, BR23, BR25, and BR30 were identified to be closely related to Exiguobacterium acetylicum, Bacillus cereus, Klebsiella quasipneumoniae, Paenibacillus polymyxa, and Acinetobacter baumannii with 98.57-100\% level of similarity.
\end{abstract}

Keywords: Buffalo rumen, cellulolytic, fiber degradation, mannolytic, palm kernel meal

\section{INTRODUCTION}

Palm kernel meal (PKM) is a solid waste produced from oil palm (Elaeis guineensis) extraction process. Oil palm is harvested in form of fresh fruit bunches (FFB). Most FFB are processed to crude palm oil (CPO) through several steps, with each step producing waste or side products, namely: empty bunches, mesocarp fibers, PKM, and palm oil mills effluent (POME). Being produced throughout the year, cheap in price, and plenty in amount, PKM has potential to be developed as an alternative feed. Indonesia is one of the largest producers of palm oil worldwide, with oil palm plantation area of 11.67 million hectares in 2016 and CPO production of 33.5 million tons (Hambali and Rivai 2017).

Use of PKM for cattle and poultry feed has been considerably researched, including for swine (Almaguer et al. 2014; Stein et al. 2015), broilers (Alshelmani et al. 2016; 2017a), and laying hens (Chong et al. 2008; Adrizal et al. 2011). PKM is proven effective as cow feed mixture up to $50-80 \%$ (Widjaja and Utomo 2004; Zahari and Alimon 2014). The research show that PKM is quite effective to be used as feed mixture for ruminants but not as effective for monogastric animals. PKM has a low digestibility, especially for monogastric animals because of its high non-starch polysaccharide (NSP) content (Alshelmani et al. 2017b). Like other plant residues, the main components of PKM cell walls contain high NSP or structural polysaccharides, composed of hemicellulose $(61.5 \%)$ and cellulose (11.6\%). Mannan is the main component of hemicellulose in PKM which comprises $57.8 \%$ of total NSP, while xylan only accounts for $3.7 \%$ of the content (Ong et al. 2004; Shukor et al. 2016). The digestibility of high-fiber plant-based feed can be improved by reducing its fiber content. Corresponding to the fiber composition in PKM, cellulolytic and mannanolytic microbes can be applied in order to reduce their fiber content through biodegradation process.

Ruminants are able to utilize lignocellulosic materials as energy sources with the help of microbial community 
inside the rumens. Rumens of ruminants are known as efficient natural fermentation agents in digesting structural polysaccharides. Buffalo (Bubalus babalis, Linnaeus, 1758) is a ruminant that has superior ability in overcoming environmental stress and adapting to a diversity of plantbased feed, even those with low quality (Jadhav et al. 2013). It has been reported that when Buffalo and cattle were kept under similar conditions, buffalo had 2-3\% higher efficiency of feed use (Wanapat and Rowlinson 2007). There are differences in digestive physiology between buffaloes and cattle, buffalo produce more rumen microflora and show better digestion of crude protein in the diet with high content of structural carbohydrates (Puppo et al. 2002). Based on the aforementioned, this research was aimed at obtaining bacteria with cellulolytic and mannanolytic abilities from buffalo rumens that may be used as agents in PKM fiber biodegradation process.

PKM digesting microbes were enriched in PKMenrichment medium and isolated by using isolation medium containing PKM as a single carbon source. Screening of hydrolytic activities was done based on clear zone formation on screening media with $\mathrm{CMC}$, LBG, and PKM as carbon sources. A total of five bacterial isolates with the highest hydrolytic activities were then assayed quantitatively for their abilities to degrade mannan and cellulose during submerged fermentation. These isolates then identified based on 16S rRNA gene sequences.

\section{MATERIALS AND METHODS}

\section{Sources of microorganism}

Bacteria were isolated from buffalo (Bubalus bubalis) rumen contents obtained from Municipal Slaughterhouse in Kudus and Demak, Central Java, Indonesia. Rumen contents were extracted in an aseptic manner from freshly slaughtered buffaloes, put into sterilized bags, and then stored in an icebox.

\section{Media}

PKM digesting microbes were enriched in enrichment medium which composed of mineral salt solution, $0.1 \%$ yeast extract and 1\% PKM. Isolation medium with the same composition added with $2 \%$ bacterial agar. PKM was dried at $50^{\circ} \mathrm{C}$, crushed and sifted by using 40 mesh sieve and then added into mineral salt solution before sterilization. For screening of cellulolytic and mannanolytic microbes used screening medium which composed of mineral salt solution, $0.1 \%$ yeast extract, $2 \%$ agar, and locust bean gum (LBG) (Sigma) for mannanolytic and Microcrystalline cellulose (MCC) (Merck) for cellulolytic. The isolated microbes were also examined for their ability to utilize PKM as their nutrient. For mannan and cellulose, biodegradation examinations used the same as screening media without agar. Mineral salt solution composition in $\mathrm{g} / \mathrm{l}$ included $\mathrm{K}_{2} \mathrm{HPO}_{4}$ (1.0), $\mathrm{KH}_{2} \mathrm{PO}_{4}(1.0), \mathrm{MgSO}_{4} .7 \mathrm{H}_{2} \mathrm{O}$ (0.2), $\mathrm{NH}_{4} \mathrm{NO}_{3}$ (1.0), $\mathrm{FeCl}_{3} .6 \mathrm{H}_{2} \mathrm{O}(0.05 \mathrm{~g})$, and $\mathrm{CaCl}_{2}$ $(0.02 \mathrm{~g})$. Carbon sources were added into mineral salt solution and then sterilized at $121{ }^{\circ} \mathrm{C}, 1$ atm for 15 minutes.

\section{Isolation and primary screening of mannanoliytic and cellulolytic bacteria}

Bacterial isolation processes were immediately conducted after the sample had arrived in laboratory (less than 48 hours). Sample of rumen contents was weighed as much as $10 \mathrm{~g}$, added with $100 \mathrm{~mL}$ of sterile $0.89 \% \mathrm{NaCl}$ solution, homogenized for 5 minutes and then sedimented. About $2.5 \mathrm{~mL}$ of the homogenates were inoculated into $22.5 \mathrm{~mL}$ of enrichment media. Incubation was conducted at $34^{\circ} \mathrm{C}$ for 24 hours with $120 \mathrm{rpm}$ agitation. About $1 \mathrm{~mL}$ culture was added with $9 \mathrm{~mL}$ of sterile $0.89 \% \mathrm{NaCl}$ so that $10^{-1}$ dilution was obtained. Then, a series of dilutions was prepared up to $10^{-5}$. In each dilution series from $10^{-3}$ to $10^{-5}$, a $0.1 \mathrm{~mL}$ sample was taken, inoculated into the isolation media using streak plate method, and then incubated at $34^{\circ} \mathrm{C}$ for 24 hours. All of separated colonies were purified by using 4-quadrant method in Nutrient Agar (NA) media. Pure culture was maintained in NA and stored at $4{ }^{\circ} \mathrm{C}$.

About 1 loop of bacterial isolates grown on NA slant ( 18 hours of age, $34^{\circ} \mathrm{C}$ ) was taken and inoculated into $2 \mathrm{~mL}$ nutrient broth (NB) media and then incubated at $34^{\circ} \mathrm{C}$ for 18 hours with $120 \mathrm{rpm}$ agitation. About $10 \mu \mathrm{L}$ of culture was inoculated on screening media and then incubated at $34^{\circ} \mathrm{C}$ for 36 hours. Hydrolytic activity was indicated by the presence of clear zone around the colonies. The clear zone was marked by coloration using Congo red $1 \%$ for 10 minutes and then washed with $1 \mathrm{M} \mathrm{NaCl}$ (Teather and Wood 1982). Hydrolytic activity was determined based on the ratio of clear zone diameter by colony diameter $(\mathrm{dz} / \mathrm{dc})$.

\section{Mannan and cellulose biodegradation assays of selected isolates}

Inoculums for biodegradation assay was produced by inoculating $2 \mathrm{~mL}$ culture from $\mathrm{NB}$ media into $8 \mathrm{~mL} \mathrm{NB}$ media and incubating at $34^{\circ} \mathrm{C}, 120 \mathrm{rpm}$, for 8 hours. From the culture of bacteria in NB medium, $1 \mathrm{~mL}$ was taken and inoculated into $9 \mathrm{~mL}$ of Mannan and Cellulose degradation Media, respectively, and then incubated at $34^{\circ} \mathrm{C}$ with 120 rpm agitation for $16 \mathrm{~h}$ and $6 \mathrm{~d}$ for mannan and cellulose degradation assays, respectively. After the incubation, the remaining substrate levels were measured. The growth of bacteria was measured by using Total Plate Count (TPC) method. The measurement of remaining mannan was conducted by measuring viscosity by using Brookfield DVE viscometer (Chauhan et al. 2014). The measurement of the remaining cellulose level was done by measuring the glucose level after acid hydrolysis. About $10 \mathrm{~mL}$ of culture was centrifuged at $3000 \mathrm{~g}$ for 5 minutes. The resulting precipitate was washed by using nitrite acetate reagent (80\% acetic acid: nitric acid $=10: 1)$ and distilled water (Updegraff (1969). Precipitate was further hydrolyzed by using $1 \mathrm{~mL} 72 \% \mathrm{H}_{2} \mathrm{SO}_{4}$ and then incubated for 2 hours at $30^{\circ} \mathrm{C}$. After incubation, distilled water was added until the concentration of $\mathrm{H}_{2} \mathrm{SO}_{4}$ reached $4 \%$ and then autoclaved for 1 hour. According to the manufacturer's guide, the glucose level of the hydrolysate was measured using GOD kit (Dyasis, Germany) according to the manufacturer's guide (Chung et al. 1997). Substrate residue level was determined based on standard curve of MCC concentration to hydrolysate's glucose level. 
Identification of selected bacterial isolates based on $16 \mathrm{~S}$ rRNA gene sequence

Five bacterial isolates with highest hydrolytic ability were identified based on their 16S rRNA gene sequences. Bacterial isolates were cultured in NB media at $34^{\circ} \mathrm{C}$ for 18 hours with $120 \mathrm{rpm}$ agitation. The culture was centrifuged at $10,000 \mathrm{~g}$ for 1 minute. The supernatant was then removed and the precipitated cells were used for DNA extraction. Genomic DNA extraction was conducted by using Presto ${ }^{\text {TM }}$ Mini gDNA Bacteria Kit (Genaid, Taiwan) according to the manufacturer's guide. Amplification of 16S rRNA gene was conducted with universal primers for bacteria, namely 63F (5'- CAGGCCTAACACATGCAAGTC-3') and 1387R (5'- CCCGGGAACGTATTCACCGC-3') (Marchesi et al. 1998). Total volume for polymerase chain reaction (PCR) amounted to $50 \mu \mathrm{L}$, comprised of $21 \mu \mathrm{L}$ ddH2O, $25 \mu \mathrm{L}$ of 2x MyTaqTM HS Red Mix, $1 \mu \mathrm{L}$ of 10 pmol 63F primers, $1 \mu \mathrm{L}$ of 10 pmol 1387R primers, and $2 \mu \mathrm{L}$ DNA template. PCR was performed using a Thermo Cycler (Applied Biosystem) machine with the following conditions: 3 minutes of pre-PCR at $95^{\circ} \mathrm{C}, 30$ cycles $(15$ seconds of denaturation at $94^{\circ} \mathrm{C}, 15$ seconds of annealing at $56^{\circ} \mathrm{C}, 30$ seconds of elongation at $72^{\circ} \mathrm{C}$ ), final elongation for 2 minutes at $72^{\circ} \mathrm{C}$, and finally, storing at $4^{\circ} \mathrm{C}$. PCR product purification and sequencing were conducted at $1 \mathrm{st}$ BASE (Singapore). 16S rRNA gene sequence was compared with data available at GenBank by using BLAST program of National Center for Biotechnology Information (http: //www.ncbi.nlm.nih.gov).

\section{Phylogenetic analysis}

Phylogenetic analysis was performed using the neighbor-joining method with MEGA 6.0. To statistically evaluate the branching, bootstrap analysis was carried out with data resampled 1000 times.

\section{Morphological observation on selected bacterial isolates}

Bacterial isolates with highest hydrolytic ability were observed for their colony and microscopic morphology. Morphological observation includes shape, color, elevation, and surface and margin character. Microscopic observation was conducted after Gram staining.

\section{RESULTS AND DISCUSSION}

\section{Isolation and screening of mannanolytic and cellulolytic} bacteria

About 34 bacterial isolates were successfully isolated after enrichment in a medium enriched with PKM. The bacterial isolates obtained were then tested for their ability in degrading fibers of PKM and their cellulolytic and monolytic activities. Hydrolytic activities were shown by forming clear zones around the colony after staining with Congo red 1\% (Figure 1). The results showed that all isolates obtained were capable of forming clear zones around their colonies on PKM media. The majority of them also had the ability to form clear zones on LBG and MCC media (Table 1). Isolate BR25 was found to have the highest hydrolytic ability on PKM media and highest mannanolytic ability as shown with $\mathrm{dz} / \mathrm{dc}$ ratio of 2.99 and 3.53, respectively. Isolate BR31 showed the highest cellulolytic ability with $\mathrm{dz} / \mathrm{dc}$ ratio score of 2.22 .

\section{Mannan and cellulose biodegradation test of selected isolates}

Five bacterial isolates with the highest hydrolytic ability as assessed by $\mathrm{dz} / \mathrm{dc}$ ratio were selected and then tested for their biodegradation activities based on their growth and ability to decrease MCC and LB substrates (Figure 2). Isolate BR25 with the highest hydrolytic ability in dz/dc ratio assessment was proven to have the highest ability in LBG and MCC biodegradation assays with substrate residues of $22.23 \%$ ( 8 hours of fermentation) and $58.60 \%$ (6 days of fermentation), respectively.

Table 1. Hydrolytic activity of cellulolytic and mannanolytic isolated from buffalo rumen on screening media with carbon sources of palm kernel meal (PKM), locust bean gum (LBG) and microcrystalline cellulose (MCC) based on clear zone diameter to colony diameter ratio $(\mathrm{dz} / \mathrm{dc})$

\begin{tabular}{|c|c|c|c|c|}
\hline \multirow{2}{*}{ Code of isolate } & \multicolumn{3}{|c|}{ dz/dc } & \multirow{2}{*}{$\begin{array}{c}\text { PKMxLB } \\
\text { x MCC }\end{array}$} \\
\hline & PKM & LBG/Man & MCC & \\
\hline BR1 & 2.16 & 1.54 & 1.56 & 5.22 \\
\hline BR2 & 1.75 & 1.27 & 0.98 & 2.17 \\
\hline BR3 & 1.78 & 1.48 & 1.21 & 3.21 \\
\hline BR4 & 2.21 & 1.60 & 1.36 & 4.80 \\
\hline BR5 & 1.51 & 1.08 & 1.35 & 2.21 \\
\hline BR6 & 1.87 & 1.19 & 1.44 & 3.22 \\
\hline BR7 & 2.45 & 1.25 & 1.48 & 4.52 \\
\hline BR8 & 1.64 & 1.22 & 1.46 & 2.94 \\
\hline BR9 & 1.52 & 1.16 & 1.03 & 1.82 \\
\hline BR10 & 1.82 & 1.01 & 1.70 & 3.12 \\
\hline BR11 & 2.02 & 1.15 & 2.08 & 4.85 \\
\hline BR12 & 1.50 & 1.09 & 1.18 & 1.94 \\
\hline BR13 & 1.70 & 1.01 & 0.88 & 1.50 \\
\hline BR14 & 2.52 & 1.87 & 1.27 & 5.98 \\
\hline BR15 & 2.07 & 1.03 & 1.93 & 4.12 \\
\hline BR16 & 2.09 & 1.49 & 1.99 & 6.21 \\
\hline BR17 & 2.06 & 1.38 & 1.66 & 4.73 \\
\hline BR18 & 1.91 & 1.35 & 1.56 & 4.03 \\
\hline BR19 & 1.67 & 1.20 & 0.87 & 1.76 \\
\hline BR20 & 1.41 & 1.06 & 1.30 & 1.94 \\
\hline BR21 & 2.65 & 1.07 & 1.64 & 4.66 \\
\hline BR22 & 1.56 & 1.33 & 1.72 & 3.58 \\
\hline BR23 & 2.80 & 1.19 & 1.71 & 5.72 \\
\hline BR24 & 1.57 & 1.41 & 1.48 & 3.28 \\
\hline BR25 & 3.53 & 2.99 & 1.88 & 19.87 \\
\hline BR26 & 2.08 & 1.00 & 1.72 & 3.57 \\
\hline BR27 & 1.25 & 1.08 & 1.37 & 1.85 \\
\hline BR28 & 2.12 & 1.25 & 1.90 & 5.02 \\
\hline BR29 & 1.49 & 1.26 & 1.94 & 3.65 \\
\hline BR30 & 1.64 & 1.83 & 2.06 & 6.21 \\
\hline BR31 & 1.47 & 1.00 & 2.22 & 3.27 \\
\hline BR32 & 1.87 & 1.08 & 1.88 & 3.80 \\
\hline BR33 & 2.13 & 1.23 & 2.04 & 5.34 \\
\hline BR34 & 2.37 & 1.30 & 1.84 & 5.66 \\
\hline
\end{tabular}




\section{Identification of cellulolytic and mannanolytic bacteria} based on 16S rRNA gene sequence

Five bacterial isolates with highest hydrolytic ability were identified based on 16S rRNA gene sequence. Identification result showed that these isolates had similarities with database available at GenBank with similarity rate between $98.57-100 \%$ (Table 2).

\section{The results of phylogenetic analysis}

A phylogenetic tree was created based on $16 \mathrm{~S}$ rRNA gene sequence of five cellulolytic and mannanolytic bacterial isolates obtained from buffalo rumens with highest hydrolytic activity and some sequences from GenBank database (Figure 3). Analysis results showed that the five isolates could further be divided into two groups. The first group consisted of Exiguobacterium acetylicum (BR14), Bacillus cereus (BR16), and Paenibacillus polymyxa (BR25), while the second group consists of Klebsiella quasipneumoniae (BR23) and Acinetobacter baumannii (BR30).
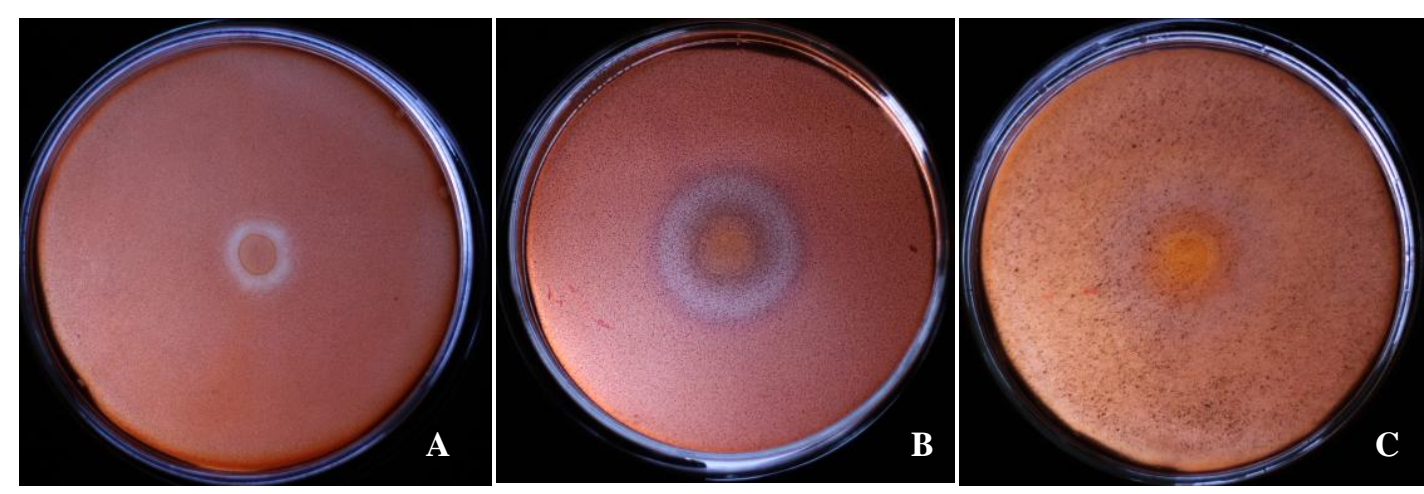

Figure 1. Isolate BR25 on screening media with carbon sources of microcristaline cellulose (A), locust bean gum (B) and palm kernel meal (C) after staining with $1 \%$ Congo red. Clear zones around the colony indicate presence of hydrolytic activity. Incubation was performed at $34^{\circ} \mathrm{C}$ for 36 hours

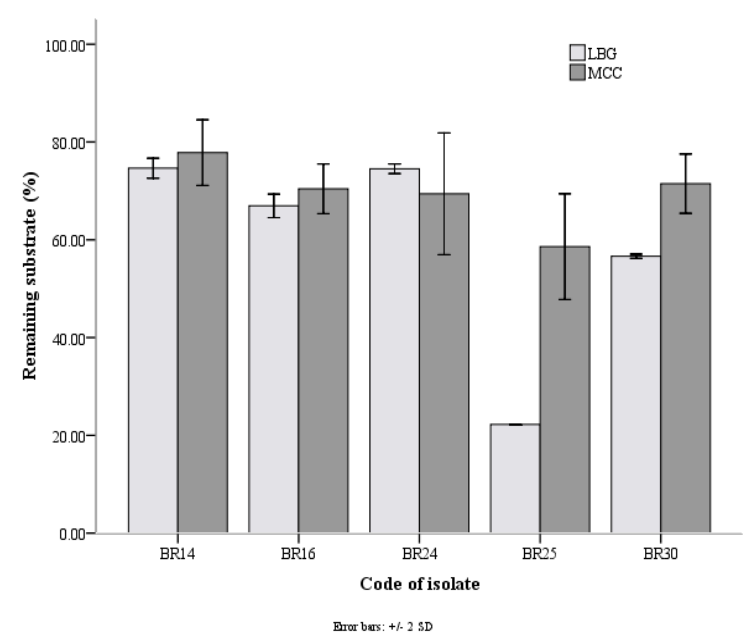

A

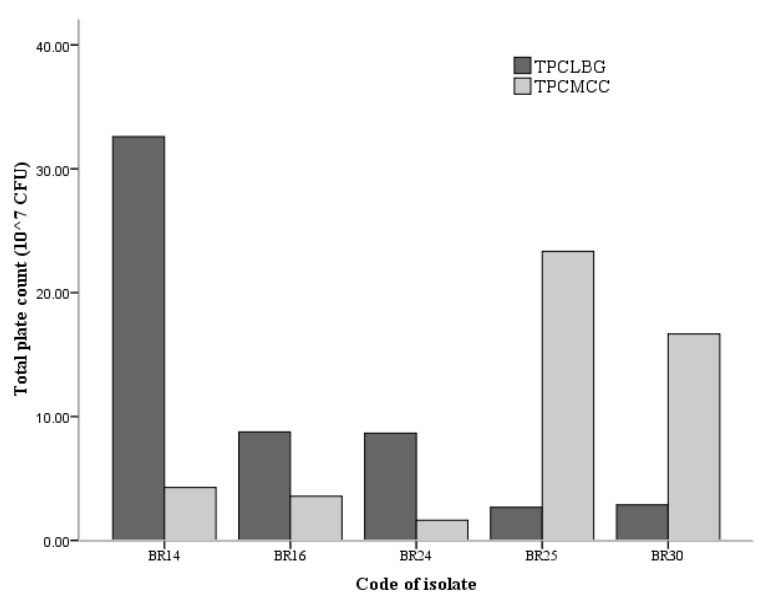

B

Figure 2. Remaining substrate level (A) and bacterial growth (B) after fermentation with single carbon sources of locust bean gum (LBG) after 8 hours fermentation and microcrystalline cellulose (MCC) after 6 days fermentation

Table 2. Identification results of mannanolytic and cellulolytic bacterial isolates from buffalo rumens based on 16S rRNA gene sequence

\begin{tabular}{clcccc}
\hline $\begin{array}{c}\text { Code of } \\
\text { isolates }\end{array}$ & \multicolumn{1}{c}{ Strain of closest match } & Per. Ident. (\%) & $\begin{array}{c}\text { Query } \\
\text { cover }\end{array}$ & $\begin{array}{c}\text { E Value } \\
\text { Accession }\end{array}$ \\
\hline BR14 & Exiguobacterium acetylicum & 98,98 & 99 & 0,0 \\
BR16 & Bacillus cereus & 99,58 & 100 & 0,0 & MN650223.1 \\
BR23 & Klebsiella quasipneumoniae & 100 & 100 & 0,0 & CP0434764.1 \\
BR25 & Paenibacillus polymyxa & 98,57 & 99 & 1 \\
BR30 & Acinetobacter baumannii & 99,57 & 100 & 0,0 \\
\hline
\end{tabular}




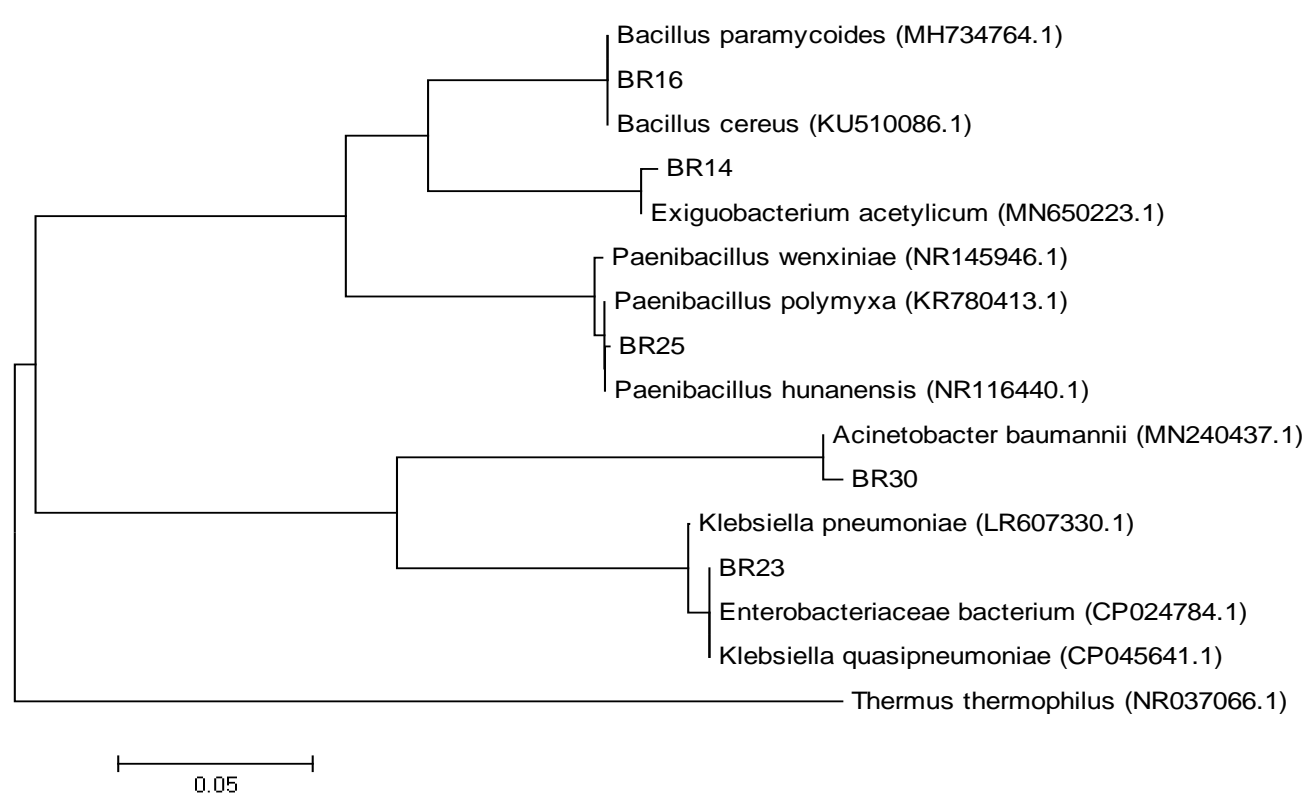

Figure 3. The results of phylogenetic analysis of five cellulolytic and mannanolytic bacterial isolates obtained from buffalo rumens with highest hydrolytic activity and some sequences from GenBank database

\section{Morphology of selected isolates}

The results of morphological observation of the colony were shown in Figure 4. Exiguobacterium acetylicum colony was circular in shape with yellow-to-orange pigmentation, wrinkled, shiny with undulate margin (Figure 4a). Exiguobacterium acetylicum was a Gramstain-positive bacterium that had coccoid or short rod shape (Figure 4b). Bacillus cereus colony was circular in shape, milky-white, waxy, opaque, and umbonate with less undulate margin (figure $4 \mathrm{c}$ ). Its cells were rod-shaped Gram-stain-positive (Figure 4d). Klebsiella quasipneumoniae colony was circular in shape, milkywhite in pigment, opaque, convex, and rough with lobate margins (Figure 4e) while its cells were short rod-shaped or coccoid and Gram-stain-negative (Figure 4f). The colony of $P$. polymyxa was circular in shape with yellow-to-orange pigmentation, low convex with a smooth, entire margin (Figure $4 \mathrm{~g}$ ). The cells of $P$. polymyxa were rod-shaped Gram-stain-positive (Figure 4h). The colony of $A$. baumannii was circular to irregular in shape, milky-white, opaque, and umbonate with undulate margin (Figure 4i) while its cells were coccobacilli in shape and Gram-stainnegative (Figure 4j).

\section{Discussion}

A majority of research concerning culturable rumen bacteria has been conducted in an anaerobic manner. It is conducted so because generally, lignocellulose biodegradation within rumen effectively happens in an anaerobic condition. However, anaerobe bacteria are very sensitive to presence of oxygen and their need for special nutrition (Kenters et al. 2011), causing them to be very difficult to handle. Therefore, in this research cellulolytic and mannanolytic bacteria from buffalo rumen were isolated in an aerobic manner. Enrichment media were used to cultivated bacteria from buffalo rumen according to obtain dominant isolates capable of growing on PKM. Lee et al. (2020) had developed a new pre-treatment system using cow rumen fluid and showed that the composition of fibrolytic bacteria in this system was greatly different from those in the in-situ rumen due to exposure to oxygen during pre-treatment. The facultative anaerobe bacteria were increased after pre-treatment.

Bacteria are the most abundant organism in rumen, being present at $10^{10}$ to $10^{11} \mathrm{~g}^{-1}$ of content and comprising approximately $50 \%$ of entire cell biomass (Creevey et al. 2014). Rumen microbes are intensively researched because their composition within rumen strongly influences rumen function (Jami and Mizrahi 2012) and supports discoveries of new microbes and enzymes for commercial use (Gruninger et al. 2014). Some microbial rumen are also recommended as feed additives to improve animal growth and productivity (Das and Qin 2012). Rumen is the source of microbes producing cellulase and hemicellulase enzymes that can be applied in various bioprocesses, feed additives, and genetic material sources for genetic engineering process (Zorec et al. 2014). 

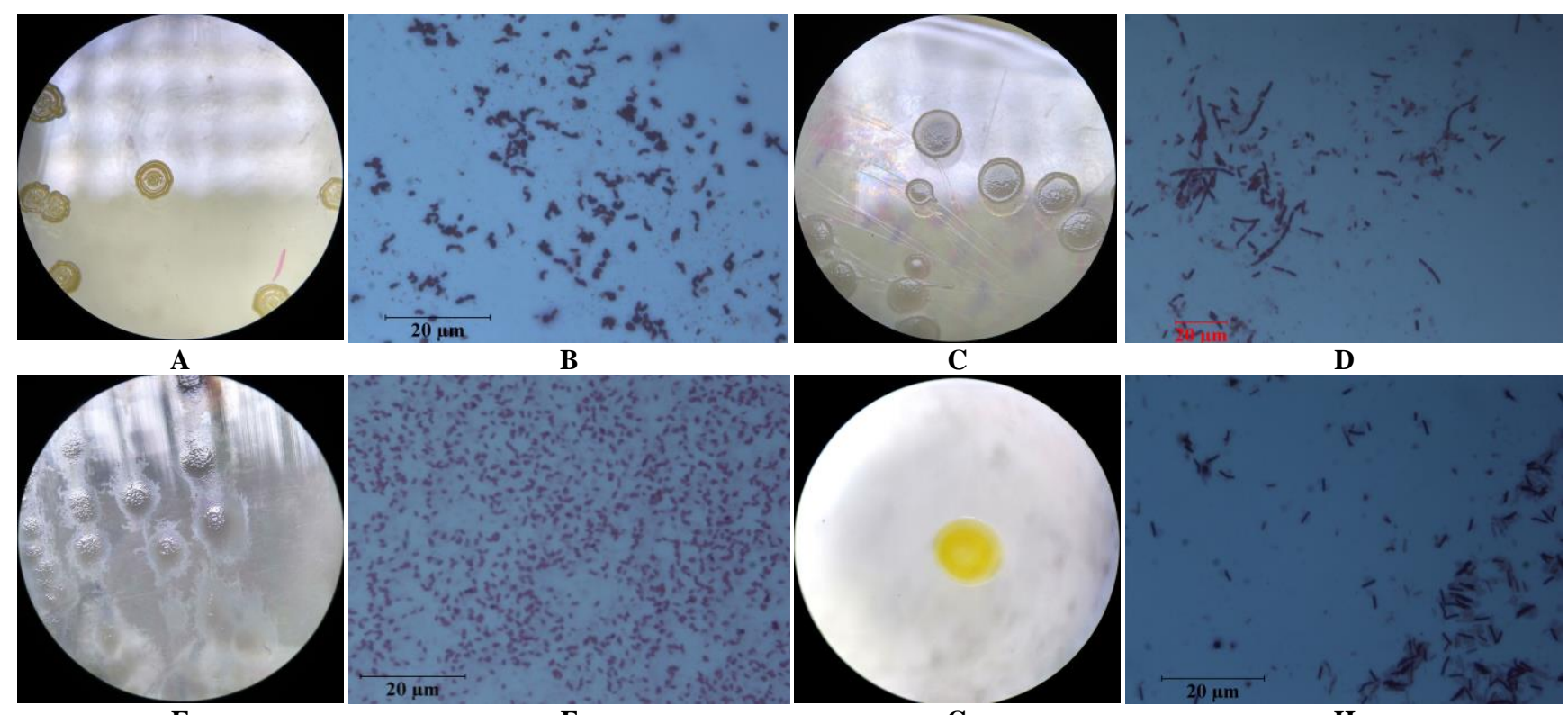

$\mathbf{F}$

G

$\mathbf{H}$
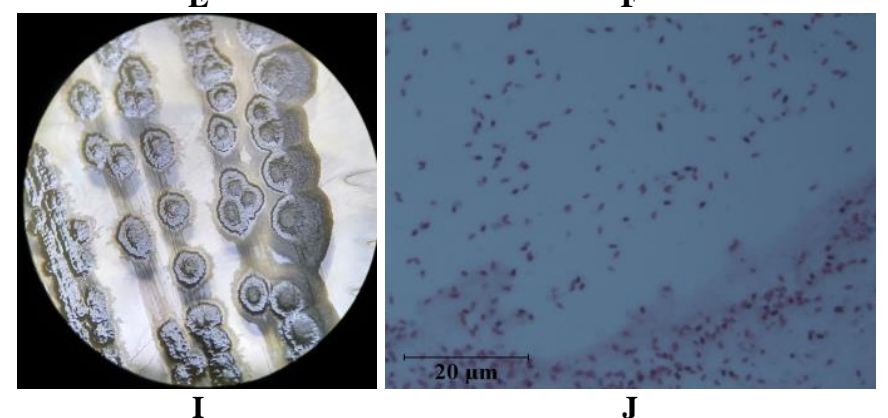

Figure 4. Colony morphology under phase-contrast microscope with 10x magnification and cell morphology after Gram staining under light microscope with 1000x magnification: A-B. Exiguobacterium acetylicum (BR14), C-D. Bacillus cereus (BR16), E-F. Klebsiella quasipneumoniae (BR23), G-H. Paenibacillus polymyxa (BR25), and I-J. Acinetobacter baumannii (BR30)

Primary screening results showed that all bacterial isolates successfully isolated in this research had the ability to produce clear zone around the colony after coloration using Congo red $1 \%$. Congo red interacts with polysaccharides that contain a $\beta$-1,4-linked backbone (Teather and Wood 1982) and both cellulose and mannan contain a $\beta$-1,4-linked backbone (Brown 2004; Liepman et al. 2007). Different color intensities occur when different carbon sources were used. Pure carbon sources such as MCC and LBG exhibit a higher color intensity than natural carbon sources such as PKM. The same results were seen in the study of Dantur et al. (2015) and Pinheiro et al. (2015) who screened cellulase activity using medium supplemented with bagasse and carboxymethyl cellulose (CMC) as sole carbon sources. Clear zones showed bacterial isolates' ability to produce extracellular enzymes to degrade polysaccharides in PKM, crystalline cellulose, and mannan used as carbon sources. In general, these isolates can produce extracellular enzymes playing important role in degradation process of carbon sources in screening media so that clear zones around the colonies can be formed. The complete degradation of plant cell walls needs synergic cooperation of cellulase, hemicellulase, and ligninase enzymes. In natural setting, degradation process is conducted by coordinated action of microbial community as the enzyme producer. Aerobic bacteria produce various individual cellulolytic enzymes with binding modules for different cellulose conformation called cellulase enzyme complex (Schwarz 2001; Zorec et al. 2014). System component of cellulase complex is classified into three groups based on their catalytic ability: endoglucanase (endoglucanase EC 3.2.1.4), exoglucanase (exoglucanase or cellobiohydrolase EC 3.2.1.91), and $\beta$-glucosidase $(\beta$ glucosidase EC 3.2.1.21) (Zhang et al. 2006). Mannanhydrolyzing enzymes consisted of $\beta$-mannanase (1,4- $\beta$-Dmannan mannohydrolase EC 3.2.178), $\beta$-mannosidase (1,4$\beta$-D-mannopyranoside hydrolase EC 3.2.1.25), and $\beta$ glucosidase (1,4- $\beta$-D-glucoside glucohydrolase EC 3.2.1.21). Additional enzymes, such as acetyl mannan esterase (EC 3.1.1.6) and $\alpha$-galactosidase (1,6- $\alpha$-Dgalactoside galactohydrolase, EC 3.2.1.22), are required to remove mannan side-chain (Moreira and Filho 2008).

Five bacterial isolates with highest hydrolytic ability as assessed in primary screening were selected and then tested for their biodegradation activities. The results showed that all selected isolates were able to grow and degrade LBG and MCC but there was no significant correlation between growth and hydrolytic ability. The ability of all selected 
isolates in degrading MCC and LBG were shown by decreasing $\mathrm{LBG}$ and MCC concentration in media after fermentation. The less of the remaining MCC and LBG level showed the highest ability in degrading MCC and LBG. Isolate BR25 showed the highest hydrolytic ability based on primary screening and biodegradation assays. Both screening methods showed the same results in BR25 but the other isolates did not show the same results. Dantur et al. (2015) and Saini et al. ( 2017) were screened cellulolytic activities based on $\mathrm{dz} / \mathrm{dc}$ ratio and quantitatively for the production of cellulases. The result showed that isolates with the highest $\mathrm{dz} / \mathrm{dc}$ showed the highest CMCase activities, but generally the $\mathrm{dz} / \mathrm{dc}$ ratio did not show correlation with the synthesis of cellulolytic enzymes in the production medium. Although the Congo red test was sensitive enough for primary isolation and screening of mannolytic bacteria, the clear zone width was not implied the amount of mannanase activity (Phothichitto et al. 2006; Harnentis et al. 2013). The bacterial ability in degrading celluloses and hemicelluloses are pivotal in its application in fermentation process to reduce fiber in plantbased feed. Previous research showed that cellulolytic and mannanolytic bacteria can increase digestion level of plantbased feed in monogastric animals through fermentation process (Alshelmani et al. 2014). Solid-state fermentation of feed by bacteria with cellulolytic and hemicellulolytic activity can reduce insoluble dietary fiber contents and increase growth performance on swine (Liu et al. 2017). The addition of exogenous fiber hydrolyzing enzymes such as cellulose and hemicellulase as supplement can improve the feed's nutritional value and digestibility (Zamani et al. 2017; Alshelmani et al. 2021).

Based on 16S rRNA gene sequence, three bacterial isolates with highest hydrolytic activity were found to be identified as members of phylum Firmicutes: Exiguobacterium acetylicum (BR14), Bacillus cereus (BR16), Paenibacillus polymyxa (BR25). Selvakumar et al. (2009) successfully isolated Exiguobacterium acetylicum which has several characteristics, namely the circular shape of its colonies with yellow pigmentation. Exiguobacterium acetylicum isolated from palm oil waste compost was reported to have cellulolytic and hemicellulolytic activity (Zainudin et al. 2013) while Exiguobacterium sp. VSG-1 isolated from the ground was reported to have lignocellulolytic activity (Vijayalaxmi et al. 2013). Lee et al. (2020) had developed a new pretreatment of lignocellulosic substrates using cow rumen fluid and found that Exiguobacterium, belonged to Bacilli, maybe the major cellulose degradation bacteria in this system. Bacillus cereus is reported as the producer of cellulase and hemicellulase enzymes (Chantarasiri 2015; El-Sharouny et al. 2015; Abu-Gharbia et al. 2018; Tabssum et al. 2018). Bacillus cereus from liquor rumen of beef cattle could be used as a probiotic candidate to improve the quality of animal feed (Lokapirnasari et al. 2017). Paenibacillus polymyxa (BR25) has the highest hydrolytic activity on PKM media and mannanolytic activity based on semiquantitative screening. These isolates also showed highest activity on mannan and cellulose biodegradation test. Paenibacillus can be isolated from various sources and is aerobic or facultative aerobic. Naghmouchi et al. (2011) successfully isolated $P$. polymixa that has antibacterial power and potential as feed probiotic. This bacterium produces polymyxin antibiotics, a group of cyclic peptides with linear side chains that have antibacterial power to Gram-negative bacterial pathogen. Paenibacillus polymyxa can degrade and use lignocelluloses' main components, which are lignin, cellulose, and hemicellulose (Weselowski et al. 2016). Genome sequence of Paenibacillus polymyxa isolated from cow rumen was reported to have potential as a candidate for lignocelluloses hydrolysis process (Bohra et al. 2018).

Klebsiella quasipneumoniae and Acinetobacter baumannii have been identified as member of Proteobacteria. Klebsiella quasipneumoniae had been successfully isolated from excreted coffee beans in Luwak feces (Iswanto et al. 2019). Some species of Klebsiella has been reported to have cellulolytic and hemicellulolytic activity including $\mathrm{K}$. pneumonia from digestive tract of Bombix morii (Anand et al. 2010), K. ozeanae (Kalaiselvi and Jayalakshmi 2013), K. oxytoca, K. variicola (Dantur et al. 2015). $K$ oxytoca produces mannanase, which can hydrolyze locust bean gum and mannan in copra and can be developed as a probiotic (Chantorn et al. 2013). Surabhi et al. (2018) successfully isolated cellulolytic bacteria identified as A. baumannii from dung beetle (Onitis philemon) digestive tract. Some species of genus Acinetobacter has been reported to be potential in biodegradation process of cellulose, including $A$. junii (Kuhad et al. 2011) and A. indicus (Karlapudi et al. 2019).

In conclusion, based on the findings of the result, it can be concluded that Paenibacillus polymyxa (BR25) is superior and may have potential to be used as microbial feed additive and source of microbial enzymes to degrade cellulose and mannan in palm kernel meal. However, advanced experiments are required to confirm the effectiveness and safety of this isolate.

\section{ACKNOWLEDGEMENTS}

This research has been supported by Beasiswa Unggulan Dosen Indonesia Dalam Negeri (BUDI-DN) through the Ministry of Research, Technology and Higher Education (KEMRISTEKDIKTI) together with Indonesia Endowment Fund for Education (LPDP).

\section{REFERENCES}

Abu-Gharbia MA, El-Sawy NM, Nasr AM, Zedan LA. 2018. Isolation, optimization and characterization of cellulases and hemicellulases from Bacillus cereus LAZ 518 isolated from cow dung using corn cobs as lignocellulosic waste. J Pharm Appl Chem 4 (2): 67-79. DOI: 10.18576/jpac/040201.

Adrizal A, Yusrizal Y, Fakhri S, Haris W, Ali E, Angel CR. 2011. Feeding native laying hens diets containing palm kernel meal with or without enzyme supplementations : 1 . Feed conversion ratio and egg production. J Appl Poult Res 20 (March): 40-49. DOI: 10.3382/japr.2010-00196.

Almaguer BL, Sulabo RC, Liu Y, Stein HH. 2014. Standardized total tract digestibility of phosphorus in copra meal, palm kernel expellers, palm 
kernel meal, and soybean meal fed to growing pigs. J Anim Sci 92 (6): 2473-2480. DOI: 10.2527/jas2013-6654.

Alshelmani MI, Loh TC, Foo HL, Lau WH, Sazili AQ. 2014 Biodegradation of palm kernel cake by cellulolytic and hemicellulolytic bacterial cultures through solid-state fermentation. Sci World J 2014. DOI: 10.1155/2014/729852.

Alshelmani MI, Loh TC, Foo HL, Sazili AQ, Lau WH. 2016. Effect of feeding different levels of palm kernel cake fermented by Paenibacillus polymyxa ATCC 842 on nutrient digestibility, intestinal morphology, and gut microflora in broiler chickens. Anim. Feed Sci Technol 216: 216-224. DOI: 10.1016/j.anifeedsci.2016.03.019.

Alshelmani MI, Loh TC, Foo HL, Sazili AQ, Lau WH. 2017. Effect of feeding different levels of palm kernel cake fermented by Paenibacillus polymyxa ATCC 842 on broiler growth performance, blood biochemistry, carcass characteristics, and meat quality. Anim Prod Sci 57 (5): 839-848. DOI: 10.1071/AN15359.

Alshelmani, MI, Loh TC, Foo HL, Sazili AQ, LAU WH. 2017. Effect of solid-state fermentation on nutrient content and ileal amino acids digestibility of palm kernel cake in broiler chickens. Indian J Anim Sci 87 (9): 1135-1140.

Alshelmani, MI, Abdalla EA, Kaka U, Basit MA. 2021. Nontraditional Feedstuffs as an Alternative in Poultry Feed. In Advances in Poultry Nutrition Research. Intech Open. DOI:10.5772/intechopen.95946.

Anand AAP, Vennison SJ, Sankar SG, Prabhu DIG, Vasan PT, Raghuraman T, Geoffrey CJ, Vendan SE. 2010. Isolation and characterization of bacteria from the gut of Bombyx mori that degrade cellulose, xylan, pectin and starch and their impact on digestion. J Insect Sci 10 (107): 1-20. DOI: 10.1673/031.010.10701.

Bohra V, Dafale NA, Purohit HJ. 2018. Paenibacillus polymyxa ND25 candidate genome for lignocellulosic biomass utilization. 3 Biotech 8 (5): 1-7. DOI: $10.1007 / \mathrm{s} 13205-018-1274-3$.

Brown RM. 2004. Cellulose Structure and Biosynthesis: What is in Store for the 21st Century. J Polym Sci Part A: Polym Chem 42 (3): $487-$ 495. DOI: $10.1002 /$ pola. 10877.

Chantarasiri A. 2015. Aquatic Bacillus cereus JD0404 isolated from the muddy sediments of mangrove swamps in Thailand and characterization of its cellulolytic activity. Egypt J Aquat Res 41 (3): 257-264. DOI: 10.1016/j.ejar.2015.08.003.

Chantorn ST, Pongsapipatana N, Keawsompong S, Ingkakul A, Haltrich D, Nitisinprasert S. 2013. Characterization of mannanase S1 from Klebsiella oxytoca KUB-CW2-3 and its application in copra mannan hydrolysis. Sci Asia 39 (3): 236-245. DOI: 10.2306/scienceasia15131874.2013.39.236.

Chauhan PS, Sharma P, Puri N, Gupta N. 2014. A process for reduction in viscosity of coffee extract by enzymatic hydrolysis of mannan. Bioprocess Biosyst Eng 37 (7): 1459-1467. DOI: 10.1007/s00449013-1118-9.

Chong CH, Zulkifli I, Blair R. 2008. Effects of dietary inclusion of palm kernel cake and palm oil, and enzyme supplementation on performance of laying hens. Asian-Aust J Anim Sci 21 (7): 10531058. DOI: 10.5713/ajas.2008.70581.

Chung YC, Bakalinsky A, Penner MH. 1997. Analysis of biomass cellulose in simultaneous saccharification and fermentation processes. Appl Biochem Biotechnol 66 (3): 249-262. DOI 10.1007/BF02785591.

Creevey CJ, Kelly WJ, Henderson G, Leahy SC. 2014. Determining the culturability of the rumen bacterial microbiome. Microb Biotechnol 7: 467-479. DOI: 10.1111/1751-7915.12141.

Dantur KI, Enrique R, Welin B, Castagnaro AP. 2015. Isolation of cellulolytic bacteria from the intestine of Diatraea saccharalis larvae and evaluation of their capacity to degrade sugarcane biomass. AMB Express 5: 15. DOI: 10.1186/s13568-015-0101-z.

Das KC, Qin W. 2012. Isolation and characterization of superior rumen bacteria of cattle (Bos taurus) and potential application in animal feedstuff. Open J Anim Sci 2 (4): 224-228. DOI 10.4236/ojas.2012.24031.

El-Sharouny EE, El-Toukhy NMK, El-Sersy NA, El-Gayar AAEA. 2015. Optimization and purification of mannanase produced by an alkaliphilic-thermotolerant Bacillus cereus N1 isolated from Ban Salama Lake in Wadi El-Natron. Biotechnol Biotechnol Equip 29 (2) 315-323. DOI: 10.1080/13102818.2014.995932.

Gruninger RJ, Sensen CW, Mcallister TA, Forster RJ. 2014. Diversity of rumen bacteria in Canadian Cervids. PLoS ONE 9 (2): 1-9. DOI: 10.1371/journal.pone.0089682.
Hambali E, Rivai M. 2017. The potential of palm oil waste biomass in Indonesia in 2020 and 2030. IOP Conf Ser: Earth Environ Sci 65. DOI: 10.1088/1755-1315/65/1/012050.

Harnentis, Marlida Y, Rizal, Y, Endo Mahata M, Words K. 2013. Isolation, characterization and production of mannanase from thermophilic bacteria to increase the feed quality. Pak J Nutr 12 (4): 360-364. DOI: 10.3923/pjn.2013.360.364.

Iswanto T, Shovitri M, Altway ALI, Widjaja TRI. 2019. Isolation and identification of caffeine-degrading bacteria from soil, coffee pulp waste and excreted coffee bean in Luwak feces. Biodiversitas 20 (6): 1580-1587. DOI: $10.13057 /$ biodiv/d200614.

Jadhav SK, Deshmukh GB, Sathapathy S, Lende SR, Sewatkar GG, Joshi SK. 2013. Fiber degradation in buffalo-an innovative approach. IOSR-JAVS 2 (5): 25-27. DOI: 10.9790/2380-0252527.

Jami E, Mizrahi I. 2012. Composition and similarity of bovine rumen microbiota across individual animals. PLoS ONE 7 (3): 1-8. DOI: 10.1371/journal.pone.0033306.

Kalaiselvi V, Jayalakshmi S. 2013. Cellulase from an estuarine Klebsiella ozeanae. Int J Curr Microbiol Appl Sci 2 (9): 109-118.

Karlapudi AP, Venkateswarulu TC, Srirama K, Dirisala VR, Kamarajugadda BP, Kota RK, Kodali VP. 2019. Purification and lignocellulolytic potential of cellulase from newly isolated Acinetobacter indicus KTCV2 Strain. Iran J Sci Technol Trans Sci 43 (3): 755-761. DOI: 10.1007/s40995-018-0600-2.

Kenters N, Henderson G, Jeyanathan J, Kittelmann S, Janssen PH. 2011. Isolation of previously uncultured rumen bacteria by dilution to extinction using a new liquid culture medium. J Microbiol Methods 84 (1): 52-60. DOI: 10.1016/j.mimet.2010.10.011.

Kuhad RC, Gupta R, Singh A. 2011. Microbial cellulases and their industrial applications. Enzyme Res 2011 (1). DOI: $10.4061 / 2011 / 280696$

Lee CG, Baba Y, Asano R, Fukuda Y, Tada C, Nakai Y. 2020. Identification of bacteria involved in the decomposition of lignocellulosic biomass treated with cow rumen fluid by metagenomic $\begin{array}{lllll}\text { analysis. J Biosci Bioeng } 130 & \text { (2): 137-141. DOI: }\end{array}$ 10.1016/j.jbiosc.2020.03.010.

Liepman AH, Nairn CJ, Willats WG T, Sørensen I, Roberts AW, Keegstra K. 2007. Functional genomic analysis supports conservation of function among cellulose synthase-like a gene family members and suggests diverse roles of mannans in plants. Plant Physiol 143 (4): 1881-1893. DOI: 10.1104/pp.106.093989.

Liu P, Zhao J, Guo P, Lu W, Geng Z, Levesque C L, Johnston LJ, Wang C, Lio L, Zhang J, Ma N, Qiao S, Ma X. 2017. Dietary corn bran fermented by Bacillus subtilis MA139 decreased gut cellulolytic bacteria and microbiota diversity in finishing pigs. Front Cell Infect Microbiol 7 (DEC): 1-9. DOI: 10.3389/fcimb.2017.00526.

Lokapirnasari WP, Sahidu AM, Nurhajati T, Soepranianondo K, Yulianto AB. 2017. Potency of Bacillus cereus WPL 415 to increase crude protein and decrease crude fiber of animal feedstuff. In KnE Life Sciences (eds), The Veterinary Medicine International Conference 2017: 579-587. DOI: 10.18502 /kls.v 3i6.1185

Marchesi JR, Sato T, Weightman AJ, Martin TA, Fry JC, Hiom SJ, Wade WG. 1998. Design and evaluation of useful bacterium-specific PCR primers that amplify genes coding for bacterial 16S rRNA. Appl Environ Microbiol 64 (2): 795-799. DOI: 10.1128/AEM.64.2.795799.1998 .

Moreira LRS, Filho EXF. 2008. An overview of mannan structure and mannan-degrading enzyme systems. Appl Microbiol Biotechnol 79 (2): $165-178$. DOI: $10.1007 / \mathrm{s} 00253-008-1423-4$

Naghmouchi K, Paterson L, Forster B, Mcallister T, Djamel SO, Teather R, Baah J. 2011. Paenibacillus polymyxa JB05-01-1 and its perspectives for food conservation and medical applications. Arch Microbiol 193: 169-177. DOI: 10.1007/s00203-010-0654-9.

Ong LGA, Abd-Aziz S, Noraini S, Karim MIA, Hassan MA. 2004. Enzyme production and profile by Aspergillus niger during solid substrate fermentation using palm kernel cake as substrate. Appl Biochem Biotechnol 118: 73-79. DOI: 10.1385/ABAB:118:1-3:073.

Phothichitto K, Nitisinprasert S, Keawsompong S. 2006. Isolation, screening and identification of mannanase-producing microorganisms. Agric Nat Resour 40 (6 (Suppl.)): 26-38.

Pinheiro GL, Correa RF, Cunha RS, Cardoso AM, Chaia C, Clementino MM, Garcia ES. 2015. Isolation of aerobic cultivable cellulolytic bacteria from different regions of the gastrointestinal tract of giant land snail Achatina fulica. Front Microbiol 6: 860. DOI: 10.3389/fmicb.2015.00860 
Puppo S, Bartocci S, Terramoccia S, Grandoni F, Amici A. 2002. Rumen microbial counts and in vivo digestibility in buffaloes and cattle given different diets. Anim Sci 75 (2): 323-329. DOI: 10.1017/S135772980005308X

Saini A, Aggarwal NK, Yadav A. 2017. Isolation and screening of cellulose hydrolyzing bacteria from different ecological niches. J Biosci Bioeng 5 (1): 7-13. DOI: 10.13189/bb.2017.050102.

Schwarz WH. 2001. The cellulosome and cellulose degradation by anaerobic bacteria. Appl Microbiol Biotechnol 56 (5-6): 634-649. DOI: $10.1007 / \mathrm{s} 002530100710$.

Selvakumar G, Joshi P, Nazim S, Mishra PK, Kundu S, Gupta HS. 2009. Exiguobacterium acetylicum strain 1P (MTCC 8707) a novel bacterial antagonist from the North-Western Indian Himalayas. World J Microb Biot 25 (1): 131-137. DOI: 10.1007/s11274-008-9874-4.

Shukor H, Abdeshahian P, Al-Shorgani NKN, Hamid AA, Rahman NA, Kali MS. 2016. Saccharification of polysaccharide content of palm kernel cake using enzymatic catalysis for production of biobutanol in acetone-butanol-ethanol fermentation. Bioresour Technol 202: 206213. DOI: 10.1016/j.biortech.2015.11.078.

Stein HH, Casas GA, Abelilla JJ, Liu Y, Sulabo RC. 2015. Nutritiona value of high fiber co-products from the copra, palm kernel, and rice industries in diets fed to pigs. J Anim Sci Biotechnol 1-9. DOI: 10.1186/s40104-015-0056-6.

Surabhi K, Rangeshwaran R, Frenita ML, Shylesha AN, Jagadeesh P. 2018. Isolation and characterization of the culturable microbes associated with gut of adult dung beetle Onitis philemon (Fabricius ). J Pharmacogn Phytochem 7 (2): 1609-1614.

Tabssum F, Irfan M, Shakir HA, Qazi JI. 2018. RSM based optimization of nutritional conditions for cellulase mediated Saccharification by Bacillus cereus. J Biol Eng 12 (1): 1-10. DOI: 10.1186/s13036-0180097-4.

Teather RM, Wood PJ. 1982. Use of Congo Red-Polysaccharide Interactions in Enumeration and Characterization of Cellulolytic Bacteria from the Bovine Rumens. Appl Environ Microbiol 43 (4): 777-780. DOI: 10.1128/aem.43.4.777-780.1982.

Updegraff DM. 1969. Semi micro determination of cellulose in biological materials. Anal Biochem 32 (3): 420-424. DOI: 10.1016/S00032697(69)80009-6.
Vijayalaxmi S, Appaiah KAA, Jayalakshm SK, Mulimani VH, Sreeramulu K. 2013. Production of bioethanol from fermented sugars of sugarcane bagasse produced by lignocellulolytic enzymes of Exiguobacterium sp. VSG-1. Appl Biochem Biotechnol. DOI: 10.1007/s12010-013-0366-0.

Wanapat M, Rowlinson P. 2007. Nutrition and feeding of swamp buffalo: Feed resources and rumen approach. Italia J Anim Sci 6 (SUPPL. 2): 67-73. DOI: 10.4081/ijas.2007.s2.67.

Weselowski B, Nathoo N, Eastman AW, MacDonald J, Yuan ZC. 2016. Isolation, identification and characterization of Paenibacillus polymyxa CR1 with potentials for biopesticide, biofertilization, biomass degradation and biofuel production. BMC Microbiol 16 (1): 1-10. DOI: 10.1186/s12866-016-0860-y.

Widjaja E, Utomo B. 2004. Pemanfaatan limbah pengolahan minyak kelapa sawit; ang berupa solid untuk pakan ternak (sapi, domba dan ayam) di Kalimantan Tengah. Succes Story. Pengembangan Teknologi Inovatif Spesifik Lokasi. Buku I. Proyek Pengkajian Teknologi Pertanian Partisipatif (PAATP). Badan Litbang Pertanian, Jakarta. [Indonesian]

Zahari MW, Alimon AR. 2014. Use of palm kernel cake and oil palm byproducts in compound feed. Palm Oil Dev 49 (July 2014): 5-9.

Zainudin MHM, Hassan MA, Tokura M, Shirai Y. 2013. Indigenous cellulolytic and hemicellulolytic bacteria enhanced rapid cocomposting of lignocellulose oil palm empty fruit bunch with palm oil mill effluent anaerobic sludge. Bioresour Technol 147: 632-635. DOI: 10.1016/j.biortech.2013.08.061.

Zamani UH, Loh CT, Foo L, Samsudin AA, Alshelmani M. 2017. Effect of feeding palm kernel cake with crude enzyme supplementation on growth performance and meat quality of broiler chicken. IJMB 2 (1): 22-28. DOI: 10.11648/j.ijmb.20170201.15.

Zhang YP, Himmel ME, Mielenz JR. 2006. Outlook for cellulase improvement: Screening and selection strategies. Biotechnol Adv 24: 452-481. DOI: 10.1016/j.biotechadv.2006.03.003.

Zorec M, Vodovnik M, Marinšek-Logar R. 2014. Potential of selected rumen bacteria for cellulose and hemicellulose degradation. Food Technol Biotechnol 52 (2): 210-221. 